\title{
A travessia perigosa: Grande sertão: veredas e Doutor Fausto em leitura dialógical ${ }^{1}$
}

MARCEL VEJMELKA

\section{Como posicionar o diálogo}

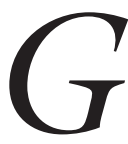

RANDE SERTÃO: VEREDAS, de João Guimarães Rosa, e Doutor Fausto, romance tardio de Thomas Mann, à primeira vista parecem muito diferentes nas suas temáticas, formas e contextos. Além das características comuns - sua importância singular nas suas literaturas nacionais e na literatura mundial, o tratamento de contextos históricos especificamente nacionais, o trabalho intenso com as suas línguas -, ficam evidentes as diferenças históricas e culturais entre o Brasil e a Alemanha, e, consequentemente, as suas respostas literárias a esses contextos imediatos. O crítico italiano Ettore Finazzi-Agrò (1998, p.112), entretanto, descreve como Grande sertão: veredas penetra na lógica do trágico, para ali "pensar a radicalidade dos conflitos e das contradições que 'não se podem, porém se devem pensar em conjunto"'. Avaliação instigante que também se aplica ao Doutor Fausto, indicando desde já qual rumo uma leitura dialógica entre dois textos tão ímpares deverá seguir: nem tanto listar as suas analogias e correspondências, e sim tornar produtiva a distância que os separa, para articular aproximações de outra qualidade.

Esse movimento se combina na proposta de Peter V. Zima (1992) para a literatura comparada como "teoria dialógica" entre crítica literária e ciências sociais, considerando não só a especificidade cultural das obras literárias, mas também das respectivas teorias. Orientado por essa concepção de uma "metateoria cultural comparatista", o que interessa aqui é veicular, na leitura dos dois romances, o diálogo crítico entre as tradições literárias e teóricas ao seu redor:

Mais importante que a ambivalência dialética é, no contexto aqui construído, a reflexão teórica [...]: Na Literatura Comparada ganha nova dimensão porque o comparatista tematiza não só a posição ideológica e os processos discursivos das teorias alheias e próprias, mas também faz da particularidade da cultura própria e alheia o seu objeto de discussão científica. (Zima, 1992, p.85)

Já existe um número reduzido de estudos comparativos de Grande sertão: veredas e Doutor Fausto que manifestam uma assimetria notável, pois todos eles foram propostos por críticos brasileiros. Igualmente é de interesse que desde logo após a publicação de Grande sertão: veredas em 1956 surgem as primeiras alusões ao romance de Thomas Mann, publicado em 1947. ${ }^{2}$ Um dos estudos 
pioneiros é o de Franklin de Oliveira (1965, p.113-24), que aproxima Mann e Rosa, relacionando os dois romances em questão por meio da figura do Fausto e da sua composição musical. ${ }^{3}$ Bastante conhecido é o ensaio de Roberto Schwarz (1983) que focaliza no "romance fáustico"4 a proximidade temática de Grande sertão: veredas e Doutor Fausto. Também no nível narrativo, Schwarz constata paralelos: a narração feita vários anos depois dos acontecimentos por Riobaldo e Serenus Zeitblom, o sertanejo e o professor alemão, narradores que dariam voz às preocupações nacionais e culturais de seus autores.

O ponto de convergência é, para Schwarz (1983, p.389), a reflexão sobre o homem e o artista num momento histórico de ameaça existencial tanto para a arte quanto para o indivíduo, representado particularmente pelo mito historicizado, por uma ambiguidade fundamental: nos dois romance não se pode saber definitivamente se houve ou não um pacto com o diabo. Enquanto o Doutor Fausto seria uma inversão da tradição do romance de formação, concretamente situado na história e no espaço, Grande sertão: veredas se manteria mais indeterminado a esse respeito. Horácio Costa (1994, p.117) utiliza o mito de Fausto para analisar o tratamento metafísico da história, a autorreferencialidade metalinguística e ironia renovada nos romances de Rosa e Mann. Porém, desliga a tradição do Fausto em Grande sertão: veredas de qualquer dimensão histórica, tratando-a como questão exclusivamente metafísica, ao contrário de um Doutor Fausto decididamente histórico.

O enfoque pela figura e tradição do Fausto é frequente na fortuna crítica. Tanto que o próprio Guimarães Rosa se viu forçado a negar a identidade de Riobaldo com o Fausto na famosa entrevista com Günther Lorenz (1995, p.59): "Não, Riobaldo não é Fausto, e menos ainda um místico barroco. Riobaldo é sertão feito homem e é meu irmão". É compreensível que tente excluir a identificação de seu personagem com modelos tão poderosos como os de Goethe ou Mann; ao mesmo tempo é inegável que Grande sertão: veredas mantenha uma relação importante com essa tradição.

Não é viável limitar-se a um elemento comparativo - nesse caso, o Fausto - porque o contato entre os dois romance faz surgir numerosos outros campos de convergência, contraste e diálogo. Da mesma forma, o Doutor Fausto não pode ser analisado exclusivamente à luz da tradição do Fausto, seja na linha popular do século XVI, seja na linha goethiana. ${ }^{5}$ Georg Lukács (1983, p.34-83) aponta para a inversão da temática do Fausto no romance de Thomas Mann, enquanto Anni Carlsson (1983, p.86) percebe ali a reelaboração e reflexão crítica do mito a partir de suas origens, fazendo coincidir o paradigma do Fausto com o da Alemanha como nação. Isso aponta outra vez para a necessidade de ampliar o enfoque analítico, para evidenciar o trabalho crítico de Thomas Mann com as dimensões históricas do mito, da tradição e da figura do Fausto no contexto alemão, concretamente à luz das duas problemáticas urgentes de sua época: os impasses da arte moderna e a catástrofe mundial provocada pela Alemanha nazista $^{6}$ 
Além de suas ligações com os diferentes Faustos da história literária e cultural, a natureza de Adrian Leverkühn e Riobaldo como pactários de forma geral os torna acessíveis nas suas dimensões culturais e existenciais tanto no nível particular quanto no universal, uma tensão que a análise aqui proposta vai condensar na sua concepção alegórica. $\mathrm{O}$ projeto historiográfico de Walter Benjamin (2000, p.450-6) tenta explorar por meio de "imagens dialéticas" a possibilidade, para o mundo posterior, de esclarecer o passado a partir de sua perspectiva no presente. A mesma sensibilidade histórica se constata em Doutor Fausto e Grande sertão: veredas, qualidade que é ainda intensificada pela leitura dialógica. Representam uma literatura que contém sempre, além de princípios filosóficos e estéticos, também a "força crítica" da própria destruição para a sua salvação pela crítica:

Trabalhar alegoricamente significa conhecer no anterior já os inícios do presente, mas também representar o que no passado estava virulento na forma ainda não esclarecida de esperanças e decepções, fantasmagorias e imaginários, e o que agora pode ser refletido e descoberto. (Bolle, 2000, p.412)

\section{Formas e representações do pacto}

Grande sertão: veredas e Doutor Fausto narram a história de uma vida que, por meio da busca existencial, trata de conflitos insolúveis no âmbito universal. Os níveis se entretecem pelas redes de relações entre as biografias narradas e suas rupturas no decorrer e na composição da narração. No centro das biografias individuais e seus contextos históricos está o pacto com o diabo, denominando a questão da culpa, da responsabilidade, da esperança e da salvação. A sua forma e representação nos dois romances difere consideravelmente, espelhando respectivamente o confronto do projeto literário com seus objetos. O motivo do pacto com o Mal, da venda da própria alma e das dúvidas provocadas é o foco mínimo que liga os romances estruturalmente. Não é o pacto que estabelece uma analogia ou um paralelo entre eles, é a respectiva origem de seus significados e o lugar de seu encontro no nível narrativo.

No Doutor Fausto o pacto é tratado em um capítulo que trata dos fundamentos filosóficos da composição musical e evidencia de forma particular a utilização e o questionamento histórico do Fausto como "leitmotiv alemão". Um diabo ilustrado disserta sobre estética e filosofia, cita Kierkegaard e Goethe, nega ironicamente toda a tradição do Fausto. Muda de aparência conforme a temática, do cafajeste ou cafetão (Mann, 2000, p.298), pelo intelectual elegante parecido com Adorno (ibidem, p.317) à figura clássica do Cujo animalesco. Explica que nem o pacto pode ter mais a forma clássica: já fora negociado e assinado há tempo, a conversa é somente a explicitação dos termos estabelecidos. Tudo fica indeciso entre sonho e realidade, não se sabe se foi um delírio - parecido ao de Ivan Karamázov, cujo "sonho febril" inspirou o capítulo -, a incerteza se intensifica pelo fato de o pacto ser narrado pelo próprio Leverkühn em anotações da manhã seguinte, que são reproduzidas literalmente por Zeitblom (ibidem, 
p.351). Para este, pouca diferença faz se houve um pacto real ou imaginado, no dois casos fica horrorizado com a perdição do amigo.

Um diálogo? Foi realmente um diálogo? Eu deveria estar louco para crer nisso. E, por essa razão, não posso tampouco acreditar que Adrian, no fundo de sua alma, tenha considerado real o que via e ouvia, seja enquanto o via e ouvia, seja mais tarde, quando o assentava no papel - não obstante o cinismo com que o interlocutor tentava convencê-lo de sua presença objetiva. Se todavia este não existia - e me horrorizo ao admitir, ainda que apenas condicionalmente, a possibilidade de sua existência real! - é pavorosa a idéia de que também aqueles argumentos cínicos, aqueles escárnios, aquelas trampolinices tenham brotado da própria alma do acossado... (ibidem, p.312)

Em Grande sertão: veredas o pacto combina elementos da tradição brasileira e europeia. O diabo não aparece fisicamente, somente é aludido e mencionado com seus inúmeros nomes da cultura popular. ${ }^{7}$ Único indício externo de sua presença são o redemoinho e outros fenômenos observados por Riobaldo, mas que sempre ficam sujeitos ao ceticismo moderno. Não há um pacto de forma clássica, apesar de Riobaldo se preparar para tal trato e juntar informações:

Em tal já sabia do modo completo, o que eu tinha de proceder, sistema que tinha aprendido, as astúcias muito sérias. Como é? Aos poucos, pouquinhos, perguntando em conversa a uns, escutando de outros, me lembrando de estórias antigo contadas. A maneira de que quase sem saber o que eu estava fazendo e querendo. De em desde muito tempo. (Rosa, 1986, p.354)

No momento decisivo da guerra contra "os judas", depois de uma tentativa interrompida, Riobaldo vai à meia-noite para a cruzilhada para invocar o Cujo. Nada acontece, o diabo não aparece e se resume em um silêncio que contém todas as suas dimensões: "Só um outro silêncio. O senhor sabe o que o silêncio é? É a gente mesmo, demais" (ibidem, p.371). O romance está permeado pela pergunta: “O diabo existe e não existe?” (ibidem, p.3). Riobaldo não sabe o que aconteceu realmente naquela noite. As consequências da dúvida são as mesmas que em Doutor Fausto, a ligação com o Mal atravessa os dois romances, independentemente do pacto ter sido concreto ou imaginado. Sem modelos literários concretos, o pacto - ou sua tentativa - em Grande sertão: veredas aponta para um deslocamento do mito ao mundo racionalizado, ao que corresponderia o permanente esforço de Riobaldo de entender e finalmente desvalidar a natureza do pacto com argumentações lógicas (Coutinho, 1995, p.20).

A situação indecisa, a falta de necessidade de um pacto formalmente assinado para ter efeito no mundo, elementos tradicionais do ritual subvertendo-o criticamente, os novos significados do motivo à luz do presente - tudo isso é comum aos dois romances. Nos dois romances o pacto se fecha sem assinatura nem sangue, só confirma uma entrega já efetuada ao Mal; o jagunço que quer deixar de ser "homem provisório" e o compositor que se contagiou há anos com a sífilis, por intermédio da prostituta Esmeralda. Diz o diabo manniano: 
Em suma, entre nós dois não há necessidade de nenhuma encruzilhada nos bosques do Spessart nem tampouco de pentagramas. Temos um pacto e concluímos um negócio. Sigilaste-os com teu sangue: comprometeste-te conosco; foi-te administrado o nosso batismo. Esta minha visita tem por objetivo unicamente a ratificação. (Mann, 2000, p.349)

E quando Riobaldo, após a morte de Diadorim, procura de novo as veredas mortas onde teme ter fechado o pacto, fica sabendo que não existem, que na verdade se chamam veredas altas.

O mal simples e tradicional foi substituído pela sua forma moderna e ambígua, a dimensão teológica do pacto se relaciona com o mundo da modernidade, onde a fé vira objeto da racionalidade e é delegada para o domínio do mito. Em Doutor Fausto isso se manifesta quando Leverkühn estuda Teologia e, em vez de se aproximar de Deus, avança no seu caminho para o pacto; em Grande sertão: veredas se encontram indícios para a situação do pacto dentro da relação entre mundo e religião. Ao mesmo tempo, o interlocutor mudo da cidade deve confirmar Riobaldo em tudo que diz respeito ao diabo, e o pacto é somente superstição e crença ultrapassada. Pedido de comprovação racional, confissão e narração aparecem como única saída de Riobaldo para solucionar o seu dilema: "Narrei ao senhor. No que narrei, o senhor talvez ache até mais do que eu, a minha verdade. Fim que foi" (Rosa, 1986, p.351).

Lleras (1995) e Kutzenberger (2005) levantam a hipótese de o pacto de Riobaldo ser uma troca de vida (ou morte) com o ser amado, Diadorim. O pacto incluiria então duas pessoas e se aproximaria da possível identidade do pactário Leverkühn e seu narrador Zeitblom no Doutor Fausto. Como em nenhum dos dois casos há certeza sobre a concretude do pacto e a relação entre os personagens Riobaldo-Diadorim e Leverkühn-Zeitblom entre complementaridade, oposição e identidade, a ambiguidade aumenta ainda mais. É marcante a correspondência entre a situação e motivação dos narradores Riobaldo e Zeitblom, ambos contando seu amor impossível por um ser perdido e morto, ambos motivados pela culpa e pela esperança de salvação - para eles mesmos e para o seu amor - por meio do narrar. Isso lança nova luz sobre o pacto, que aqui aparece como funcionar entre dois personagens envolvidos em um amor supostamente impossível. Riobaldo não pode amar Diadorim em vida por não perceber que é mulher e não admitir a possibilidade de um amor homossexual, um aspecto que se liga à sua culposa falta de coragem. "Ela é, como seu próprio nome sugere, Deus e diabo, luz e trevas, carne e espírito, dor e prazer, homem e mulher, e constitui pela contradição a imagem do questionamento presente em toda a obra rosiana" (Coutinho, 1995, p.22). Diadorim, moça guerreira disfarçada de homem, não pode se revelar antes de cumprir a vingança pelo pai assassinado, mas essa tarefa implica o pacto de Riobaldo e a morte dela, sacrificando-se por Riobaldo. "O senhor lê. De Maria Deodorina da Fé Bettancourt Marins - que nasceu para o dever de guerrear e nunca ter medo, e mais para muito amar, sem gozo de amor..." (Rosa, 1986, p.535). Assim, Diadorim sofre a mesma proibição de amar que Leverkühn, o 
que se combina com a sua ambiguidade, que, por sua vez, a aproximaria do motivo complexo da Esmeralda no Doutor Fausto (Vejmelka, 2008b), a borboleta amazônica e prostituta húngara que sela o pacto com Leverkühn e como invisível aristocrata magiar o protege com o seu amor distante.

Também o relato de Zeitblom é toda uma declaração de um amor nunca declarado pelo amigo morto. "[E]u o amei, com horror, ternura, compadecimento e devota admiração, sem perguntar-me sequer se ele, por pouco que fosse, correspondia aos meus sentimentos” (Mann, 2000, p.12). Leverkühn está envolto em um solidão quase absoluta, igualável à prisão que sofre Diadorim no seu secreto de ser mulher, e a reflexão de Zeitblom sobre a impossibilidade do amor por Leverkühn se aplica também a ela, modificando as formas de perceber os dois personagens:

Mas, amar-me? A quem teria amado esse homem? Talvez, em tempos idos, a uma mulher. Pelo fim, possivelmente a uma criança. A um jovem leviano, capaz de conquistar a simpatia de qualquer um, homem de todas as horas, que ele depois despachou - provavelmente por ter-se-lhe afeiçoado -, e logo à morte. A quem teria Adrian aberto o coração? A quem teria jamais acolhido em sua vida? Tais atitudes não existiam para ele. (ibidem, p.13)

Nos dois romances aparecem representantes do diabo que elucidam respectivamente as dimensões do pacto. No encontro com o fazendeiro sêo Habão, Riobaldo reconhece a sua condição de jagunço e "homem muito provisório", para depois procurar no pacto a força necessária para matar Hermógenes e a confirmação de seu futuro como dono de terras, gado e gente (Rosa, 1986, p.362). ${ }^{8}$ A visita do agente musical Saul Fitelberg é uma tentativa de chamar o compositor pactário para o mundo, de confirmar o pacto, mas também de the dar uma dimensão que contrabalança da perdição isolacionista de Leverkühn e da Alemanha a caminho do nazismo (Mann, 2000, p.554ss).

Os dois encontros não têm efeitos imediatos, somente quando lidos desde o fim dos romances é que fica evidente a sua função de sintetizar e anunciar a natureza dos tratos já vigentes. Um detalhe fascinante nessa aproximação é que o capítulo dedicado à visita de Fitelberg é introduzido pelo narrador Serenus Zeitblom, que logo propõe: "Melhor será deixá-lo com a palavra, já que as respostas dadas por Adrian e por mim ou os apartes que ocasionalmente lançávamos na conversa tinham pouquíssima importância" (ibidem, p.556).

A seguir e durante umas dez páginas, fala exclusivamente o agente francês, sem marcas textuais de ordenamento. Fala para Leverkühn e Zeitblom, que permanecem mudos, mas que ocasionalmente fazem perguntas ou dão respostas, deduzíveis pelos comentários de Fitelberg - "- Mas como? O senhor não rege? Não o faz nunca? E tampouco quer atuar como pianista? Recusa acompanhar suas mélodies?" (ibidem, p.561) -; fala assim, refletido por interlocutores invisíveis e mudos, para o leitor, com os mesmo recursos e efeitos como Riobaldo em Grande sertão: veredas. 


\section{O espaço alegorizado: Kaisersaschern e o Liso do Suçuarão}

Lugar simbólico para o tratamento da história no Doutor Fausto é a cidade natal de Leverkühn, Kaisersaschern, síntese de características de diferentes cidades alemãs, situada ao sul de Halle, perto de Leipzig, Weimar, Dessau e Magdeburg (Mann, 2000, p.49), no centro geográfico da Alemanha, na região de Lutero e da Reforma protestante. Cidade fictícia que contém tempos históricos superpostos, como descreve Zeitblom:

[N]o seu ar pairava ainda um quê do espírito dos homens dos últimos decênios do século XV, a histeria do declínio da Idade Média, algo de uma latente epidemia psíquica. Talvez seja estranho afirmar essas coisas com relação a uma sobriamente sisuda cidade moderna - porém ela não era moderna, era velha, e velhice é passado que se tornou presente, é passado apenas recoberto de presente [...]. (ibidem, p.55)

Kaisersaschern como forma espiritual de vida", inspirada em Lübeck, a cidade natal de Thomas Mann (1990, p.1131), funciona como ponto focal para a rede de símbolos e motivos dispersos pelo romance: "A questão do conteúdo histórico do romance e da imagem da Alemanha de Thomas Mann, portanto, depende em última instância da compreensão desta cidade" (Vaget, 1977, p.202). Refletido por meio da Alemanha contida na miniatura da "metáfora urbana", o nazismo aparece como a perda de rumo e destino original do país, uma dialética focalizada no pacto de Leverkühn como inversão e perversão de uma Alemanha originalmente universalista (Plessner, 2001, p.56; Wißkirchen, 1998 , p.192) simbolizada por sua vez no deslocamento da tumba de Otto III de Aachen para Kaisersaschern, do imperador morto em 1002 que personifica o conflito interno da Alemanha entre provincianismo e cosmopolitismo, tensão transposta ao herdeiro dessa tradição antiga e ao mesmo tempo o moderno pactário alemão, do qual diz o seu amigo Zeitblom:

Ele não nascera em vão na cidade onde jazia sepultado Otto III. Sua antipatia à germanidade encarnada em sua própria pessoa $[\ldots]$ manifestava-se sob a dupla forma de uma couraça de timidez em face do mundo e de uma necessidade íntima de vastidão e horizontes amplos [...]. (Mann, 2000, p.232)

Tensão sensível na obra musical de Leverkühn, de orientação cosmopolita, e ainda em discussões políticas entre as duas Guerras Mundiais, respondendo a posições ingênuas e perigosas de jovens nacionalistas com a consciência do contexto europeu na história cultural: “- Isso seria tão tipicamente alemão? - perguntou Adrian. - Em outros tempos, o ato de renascer chamava-se rinascimento e produzia-se na Itália. E o retour à la nature foi inicialmente recomendado em francês" (ibidem, p.167).

O pactário moderno não é identificado com a Alemanha entregue ao nazismo, segundo Vaget (1977) ele é representante e antípoda da Alemanha, antecipando com a sua vida o destino histórico do país. Na conversa com Leverkühn em Palestrina, o próprio diabo lembra que eles dois representam a Alemanha miniaturizada em Kaiseraschern: 
Se tivesses a necessária coragem para dizer-te: "Lá onde estou é Kaisersaschern”, a coisa ficaria certa de um momento para outro, não? [...] Terias toda razão de dizer isso, apenas não tens ou finges não ter bastante topete. [...] É bem verdade que sou alemão, genuinamente alemão, não o nego, e todavia da estofa antiga, da melhor, que no seu íntimo é cosmopolita. (Mann, 2000, p.319)

As posições se invertem, o diabo se afirma como representante de uma Alemanha original, universalista - qualidade que também Leverkühn vai assumir por meio do pacto, mas que também vai negar, retirando-se do mundo e orientando a sua obra musical exclusivamente por fontes alemãs. Leverkühn critica e representa simultaneamente o afã universalista contido no delírio nacionalista que a Alemanha segue ao entrar na Primeira Guerra Mundial:

E quem ousará negar que uma genuína abertura de caminho equivale àquilo que o mundo mansinho qualifica de crime? Espero que não penses que eu menospreze a idéia cuja manipulação no palheiro tanto te apraz. No fundo, existe neste globo somente um único problema, e este se chama: como se abre caminho? como se chega ao ar livre? como se rompe o casulo, para vir a ser borboleta? Essas perguntas dominam a situação geral. (ibidem, p.433)

Zeitblom percebe que seu amigo distingue entre ambições perigosas e destino nacional, e que, entretanto, é justamente esta posição que caracteriza a Leverkühn como alegoria da Alemanha na sua conflitividade e perdição histórica:

Talvez vás dizer que debulho a palha vazia, na qual dormíamos, mas sinto, sempre senti e manterei essa minha opinião, apesar de todas as aparências brutais, que esse afã é alemão kat'exochen, é mesmo o que define a germanidade, um estado de alma ameaçado de quimeras, do veneno da solidão, de um provincialismo boçal, de maranhas neuróticas, de silencioso satanismo... (ibidem, p.434)

A única possibilidade de "romper o casulo" para voltar à vocação universalista original se apresentaria ainda na obra musical, encontrando ali uma nova forma expressiva. Justamente com a Lamentação do Doutor Fausto, extremamente carregada de isolamento alemão, Leverkühn revela essa vocação universalista e antecipa outra vez a história da Alemanha, criando com a sua obra derradeira e desesperada a expressão da esperança para o seu país, já derrotado na Segunda Guerra e culpável para além de toda imaginação.

Essa dimensão mítica e simbólica da cidade encontra um paralelo no papel do sertão no romance de Guimarães Rosa: nos dois casos se utilizam lugares existentes na sua forma real, os modelos são reconfigurados e reinventados para elevar o seu significado ao nível simbólico; nos dois casos se estabelece uma oposição entre o ideal da Modernidade e um atraso histórico vivido. Em Grande sertão: veredas, entretanto, a localização geográfica não pode ser determinada com exatidão. No início de seu relato, Riobaldo explica que nem os próprios habitantes concordam a respeito da extensão e dos limites do sertão:

Lugar sertão se divulga: é onde os pastos carecem de fechos; onde um pode torrar dez, quinze léguas, sem topar com casa de morador, e onde o criminoso 
vive seu cristo-jesus, arredado no arrocho de autoridade. [...] O gerais corre em volta. Esses gerais são sem tamanho. [...] O sertão está em toda a parte. (Rosa, 1986, p.1)

Willi Bolle, analisando Grande sertão: veredas à luz de relatos de viagens pelo sertão no século XIX, entende a natureza alegorizada no romance como leitura de uma paisagem, ligando assim o sertão como região com a história do pensamento no Brasil, com a importância da paisagem no romantismo alemão para a construção da identidade nacional, finalmente com o mapa simbólico de Poty, que acompanhava as primeiras edições do romance. Essa reflexão se condensa no Liso do Suçuarão, microcosmo do sertão onde se intensifica a representação desse espaço, de maneira análoga à condensação "dos sertões" no sertão de Canudos. O Liso é para Bolle fronteira e centro do sertão rosiano, terra incognita e centro do mundo, como também afirmou Costa Lima com respeito ao país real desconhecido pelas elites brasileiras (cf. Bolle, 1998, p.261 3; Cunha, 1995, p.29; Costa Lima, 1997, p.193-207).

Para Bolle, a superposição de geografia real e fictícia, o deslocamento e a invenção de lugares e regiões, o significado dos rios no romance, particularmente a mistificação a partir de condições reais, possuem uma função fundamental. Rosa historiza a paisagem, carrega-a com a história e com as dimensões culturais e sociais. Por meio do trabalho com a e na natureza, deve ser recuperada a história da civilização, da nação brasileira em formação, em contraste com a sua natureza indômita e amplidão incomensurável. Imediatamente ressurge o confronto com o carregamento histórico da região no interior do Brasil, como lugar da exploração e conquista, finalmente na época moderna como símbolo do atraso e da miséria da qual iria surgir o conflito da jovem nação para manifestar-se em Canudos e ameaçar até hoje a autoimagem nacional e civilizatória.

Em Grande sertão: veredas, o sertão surge através dos olhos de Riobaldo, como oposto e ambiente da vida ao mesmo tempo; é elemento constitutivo para a percepção de si próprio como sujeito e das suas relações com a sociedade, no romance natureza concreta e paisagem se tornam meio de reflexão sobre a natureza humana. O Liso do Suçuarão é descrito como deserto interior do sertão, intensificando pelo contraste os seus lados verdes e bonitos. A interpenetração de natureza e ser humano se manifesta quando Riobaldo, na véspera de sua primeira tentativa de atravessar o Liso, sente um medo indeterminado, e entrando no Liso observa muito atentamente como a natureza se retira cada vez mais:

Mas o terreno aumentava de soltado. E as árvores iam se abaixando menorzinhas, arregaçavam saia no chão. De vir lá, só algum tatu, por mel e mangaba. Depois, se acabavam as mangabaranas e mangabeirinhas. Ali onde o campo largueia. Os urubus em vasto espaceavam. Se acabou o capinzal de capim-redondo e paspalho, e paus espinhosos, que mesmo as moitas daquele de prateados feixes, capins assins. Acabava o grameal, naquelas paragens pardas. Aquilo, vindo aos poucos, dava um peso extrato, o mundo se envelhecendo, no descampante. Acabou o sapé brabo do chapadão. (Rosa, 1986, p.37) 
O medo de Riobaldo aumenta na medida em que o grupo penetra no deserto hostil, e a consciência de estar dentro do Liso é tão sufocante que antecipa o fracasso:

A gente olhava para trás. Daí, o sol não deixava olhar rumo nenhum. Vi a luz, castigo. Um gavião-andorim: foi o fim de pássaro que a gente divulgou. Achante, pois, se estava naquela coisa - taperão de tudo, fofo, ocado, arrevesso. Era uma terra diferente, louca, e lagoa de areia. (ibidem, p.37)

Assim o Liso do Suçuarão é uma imagem potenciada do sertão, mas também de Riobaldo. Atravessando o deserto de pedras em brasa, na busca desesperada por poços d'água Riobaldo sofre alucinações e ataques de pânico; ideias confusas sobre o pactário Hermógenes e o inferno passam pela sua cabeça, uma luta que se trava dentro dele. Ele sonha com Diadorim por baixo de um arcoíris, no dia seguinte ele aspira ao matrimônio sossegado com Otacília, em seguida passa a preocupar-se exclusivamente consigo mesmo. O que Riobaldo vê é como a descida ao domínio do diabo, aos abismos dos próprios medos e maldades: "Do sol e tudo, o senhor pode completar, imaginando; o que não pode, para o senhor, é ter sido, vivido. Só saiba: o Liso do Suçuarão concebia silêncio, e produzia uma maldade - feito pessoa!" (ibidem, p.40).

Todo ao contrário se apresenta a segunda travessia, quando Riobaldo já realizou a sua tentativa de pacto. Desde o início Riobaldo sente determinação e confiança, no caminho encontra inúmeras formas de vida - plantas e animais - e há água em abundância. De noite, porém, acontece algo estranho: Riobaldo é atacado por um de seus homens e o mata a faca. Lembrando esse episódio, Riobaldo se assusta com o que fez; a travessia se conseguiu sem dificuldades, mas no seu interior se mostra uma escuridão imensa.

Para Friedman Apel (1998), o Doutor Fausto é um romance exemplar do tratamento da interiorização relacionada com a visão da paisagem e da natureza na Alemanha. Uma combinação que experimenta e lê a natureza como uma linguagem, transpondo essa legibilidade para a experiência absoluta aspirada, interpretando a natureza com um olhar culturalmente determinado e com significados culturais. Também Apel (1998) recorre a Benjamin para analisar esse encontro da abstração com a contemplação especulativa da natureza no romantismo alemão, o olhar sobre a natureza se torna busca inconsciente do esclarecimento pelo seu lado obscuro, o inconsciente, o irracional, um significado mais profundo do mundo do que pode fornecer a razão.

No Doutor Fausto a paisagem tem um papel fundamental para a vida e o caráter de Leverkühn, é tratada e questionada em analogia com a temática do ser alemão. A natureza e seus significados românticos também são objeto das discussões estudantis durante as excursões nas serra de Turíngia, sempre em estreita ligação com questões da música, como lembra Zeitblom:

Nesse círculo dava-se grande apreço à Música, ainda que o fizessem apenas de certo modo bem impreciso: via-se nela uma arte divina e cumpria ter com ela uma 
"relação" - relação essa ao mesmo tempo romântica e fervorosa, assim como a que se tinha para com a Natureza. (Mann, 2000, p.161)

A natureza carregada com significados essenciais se combina com a ideia, basicamente vazia, do "ser alemão": uma imagem da percepção esvaziada da natureza que no final do romance encontra o seu símbolo mais crítico, quando o Leverkühn agonizante nada mais sente do que o perfume de uma tília.

Em Rosa a paisagem do sertão adquire a forma da personificação e espacialização, para ser relacionada com o discurso literário e político. Por trás desse movimento está o significado do sertão no confronto histórico do Brasil com a sua própria identidade como nação. Assim Rosa realiza um carregamento duplo da natureza; essa espelha o interior de Riobaldo e representa a dualidade do pensamento civilizatório, fazendo surgir, no relacionamento mútuo, um confronto com um lugar e um tempo que para os habitantes das grandes cidades são estranhos e perdidos. Mas ao mesmo tempo as descrições da natureza em Grande sertão: veredas possibilitam enfocar criticamente esse mundo urbano invisível. Lembra-se das reflexões de Adorno (2000, p.111) acerca da beleza da natureza, de que na arte sempre é mediada, sempre representa um confronto com o seu polo oposto, a beleza humana, contendo sempre uma dimensão histórica.

Dessa forma, paisagem e cidade - fictícias e simbólicas, situadas no espaço real - incorporam em Thomas Mann uma condição mental e cultural em perspectiva histórica, uma entrada ao problema da "interiorização" alemã, como representação espacial de uma identidade cultural. O projeto rosiano está baseado concretamente no espaço geográfico regional, tratando ali a sua oposição com o Brasil supostamente moderno. Ao questionarem as condições de sua escrita e existência, os dois textos refletem criticamente sobre a culpabilidade da cultura letrada.

Mann e Rosa tratam desse complexo a partir de suas condições e necessidades históricas específicas. Rosa enxerga e problematiza o sertão como lugar do conflito interno da formação nacional do Brasil no passado e no presente. Descrevendo e reelaborando detalhadamente as circunstâncias concretas e marcantes do sertão - particularmente a miséria da população, a violência da lei do mais forte e o poder incomensurável da natureza, mas também e ao mesmo tempo o desparecimento de toda uma forma de vida em consequência da modernização - se pergunta como seria possível um pensamento brasileiro que revertesse e superasse de modo realista a visão propagandística do “político" Zé Bebelo: "Dizendo [Zé Bebelo] que, depois, estável que abolisse o jaguncismo, e deputado fosse, então reluzia perfeito o Norte, botando pontes, baseando fábricas, remediando a saúde de todos, preenchendo a pobreza, estreando mil escolas” (Rosa, 1986, p.111).

No caso da "interiorização alemã" como problema para Thomas Mann, o espírito está reduzido a si próprio e ao seu posicionamento perante a sociedade, se reconhece como motivo e motivador da catástrofe histórica do fascismo, ao 
mesmo tempo como seu oponente impotente ou culposamente passivo (Adorno, 2000, p.177). Uma imagem expressiva se encontra na tentativa de Zeitblom de explicar por que ele nunca se opôs nas reuniões sociais na casa dos Kridwiß, nas discussões sobre a superação destrutiva do existente, sobre a falsa ideia de raças superiores e um esteticismo bárbaro.

Mais indicado teria sido que eu, junto com os demais componentes da animada távola redonda, me empenhasse em observar e estudar as idéias novas, em vez de opor-lhes argumentos estéreis, no fundo completamente enfadonhos. Que tal se eu ajustasse minhas concepções ao rumo dos debates e avistasse, no decorrer de seu andamento, uma imagem do mundo futuro, a essa altura já em gestão quaisquer que fossem as reações do meu estômago? (Mann, 2000, p.514) ${ }^{9}$

O relato de Riobaldo é a grande confissão de uma culpa consciente, ao mesmo tempo a representação sem explicação dos acontecimentos, que se amplia até espelhar a posição de quem, como letrado, sabe exatamente quais são os fundamentos da formação de seu entorno e que tem a consciência incômoda da sua própria impotência. Voltando para dentro do texto, a fala de Riobaldo também expressa o conflito interno de seu interlocutor invisível mas sensível, que anota e acaba escrevendo. Pela última vez o foco narrativo se sobrepõe a si mesmo, e por trás do protagonista narrador aparece o seu outro: não o autor como pessoa, mas abstraído como meio da consciência e do saber moderno, que é o único capaz de traduzir esta fala e seu mundo para o mundo dos leitores.

O romance, segundo Benjamin (1999, p.402), suspende a temporalidade na busca de um sentido na vida, e inevitavelmente tem que ter um fim, não passa de lá e representa um convite ao leitor para buscar o sentido da vida. Tanto Thomas Mann quanto Guimarães Rosa enfrentam as limitações impostas à forma por eles criada. O narrador Zeitblom inicia o "epílogo" do Doutor Fausto com as palavras: "Está feito" (Mann, 2000, p.701), a seguir se pergunta se cumpriu a sua tarefa e qual será o destino de sua escrita, descreve os últimos anos de vida de Leverkühn em delírio mental e termina com uma imagem da esperança dolorosa: "Um homem solitário junta as mãos e diz: 'Que Deus tenha misericórdia de vossas pobres almas, meu amigo, minha pátria!'” (ibidem, p.709). Está em jogo a salvação do pactário, o futuro da Alemanha e da humanidade.

Grande sertão: veredas transgride os seus limites formais até na pontuação. As últimas palavras de Riobaldo narrador denominam a aceitação consciente da natureza indefinível do ser, do movimento infinito da vida: "Nonada. O diabo não há! É o que eu digo, se for... Existe é homem humano. Travessia." (Rosa, 1986, p.538). O signo do infinito em vez da palavra "fim”, que é inevitável mas ficou marcada a sua rejeição, a sugestão de uma leitura circular sem fim. Que cada leitor decida individualmente, assim os dois romances apontam para além da sua forma literária, formulando a questão desafiadora pelas suas possibilidades enquanto literatura.

Outra vez aparece o motivo do pacto, entendido também como "origem" no sentido benjaminiano, como ponto de contato imediato e central entre Dou- 
tor Fausto e Grande sertão: veredas, como foco da pré-história que no dois romances torna visíveis as dimensões históricas de seus objetos, onde começam, se bifurcam e se superpõem a alegorização da nação e da história contemporânea com a crise estética do seu presente, com a sua representação formal nos textos literários e o posicionamento dos escritores perante a obra e a sociedade. Desde dentro dos textos, a imagem da encruzilhada se superpõe ao encontro das leituras em diálogo. Ali se cruzam as linhas e se manifesta o que têm em comum e o que os separa, motivando em um texto questões a serem tratadas no outro. $\mathrm{O}$ pacto se multiplica para determinar uma biografia individual, uma história nacional, um presente social, para ligar os autores e a sua escrita, incluindo ali os leitores. ${ }^{10}$ Porque a encruzilhada - lugar do pacto e do encontro - também evidencia a necessidade da decisão, como a tomaram - ou não - os protagonistas Riobaldo e Adrian Leverkühn, como a devem tomar os leitores e críticos.

Friedrich Nietzsche (1999, p.511), uma influência fundamental para o Doutor Fausto e o pactário Adrian Leverkühn, faz Zaratustra descrever o ser humano: "Uma perigosa travessia, um perigoso estar-a-caminho, um perigoso olhar para trás, um perigoso tremer e ficar-parado". No final de seu relato, Riobaldo fala do "homem humano" como essência ambígua da natureza humana; também a imagem da "travessia" e do "estar-a-caminho" é central em Grande sertão: veredas, muito próxima do "romper o casulo" e o "abrir caminho" no Doutor Fausto. O homem e sua tarefa no mundo se combinam com os perigos e desafios da reflexão, como Nietzsche os evidenciou e acabou sofrendo. Esses perigos e desafios se apropriam desde dentro dos textos e seus contextos do Doutor Fansto e de Grande sertão: veredas, que os assumem e reivindicam do leitor que assuma esse mesmo perigo da leitura.

\section{Notas}

I O presente texto foi adaptado do capítulo 4 da minha tese de doutorado (Vejmelka, 2005, p.215-442).

2 Essa cronologia faz surgir a pergunta pela possível influência do romance de Mann no de Rosa. Gabriela Hofmann-Ortega Lleras (1995) analisa Grande sertão: veredas como "recepção produtiva" e até "crítica" do Doutor Fausto, que ali figuraria como um "prétexto". Entretanto, faltam as provas concretas das eventuais leituras que Rosa fez do Doutor Fausto. Respeito a outras leituras de Rosa da obra manniana (cf. Soethe 1999; Sperber, 1976).

3 Uma primeira aproximação, não aprofundada, dos autores e romances se encontra em Oliveira (1959, p.176-86).

$4 \mathrm{Na}$ perspectiva alemã, o conceito do "fáustico" virou praticamente inoperável, em razão de sua carga ideológica acumulada em diversas apropriações e abusos - por exemplo, por Oswald Spengler em A decadência do Ocidente, e sobretudo pelos nazistas (cf. Schwerte, 1962). O próprio Schwerte não escapou a essa ideologia: em 1992 foi descoberto que em 1945 tinha mudado de identidade e que, na verdade, fora pactário dos 
nazistas e oficial da SS. O mesmo problema surge no estudo de Fani Schiffer Durães (1999) que compara Riobaldo e o Fausto goethiano por meio do "homem fáustico".

5 Mann tentou "evitar" o Fausto goethiano, que não aparece no romance, referindo-se fortemente ao Fausto popular do Volksbuch, de 1580. A crítica enfrenta até hoje os problemas do conceito do "fáustico", cuja carga ideológica se complica no tratamento que Mann dá ao Fausto como alegoria da Alemanha nazista (cf. Gockel, 1988, p.148; Aßmann, 1975).

6 Existe ainda um estudo mais recente de Wilson Madeira Filho (1998) comparando um Mann "político" e um Rosa "metafísico", porém sem conhecimento da fortuna crítica de Mann.

7 Kutzenberger (2005) lista os nomes do diabo, a base das listagens anteriores de Leonardo Arroyo, João Adolfo Hansen e Pedro Xisto.

8 Para Willi Bolle (1997-1998, p.33), seô Habão é o "padrinho do pacto".

9 Rosa (2001) vivenciou esse mesmo contexto como cônsul adjunto em Hamburgo de 1938 a 1942. Ver também Ginzburg (no prelo) e Vejmelka (2008a, p.97-120).

10 Essa capacidade do literário de guardar e comunicar questões de compreensão e valores para além das condições individuais, regionais e nacionais, ao longo dos tempos e ordens epistemológicas, implica uma responsabilidade que a crítica literária está interpelada a assumir com urgência cada vez maior (cf. Ette, 2004).

Referências bibliográficas

ADORNO, T. W. Ästhetische Theorie. Frankfurt/Main: Suhrkamp, 2000.

APEL, F. Deutscher Geist und deutsche Landschaft: eine Topographie. München: Knaur, 1998.

AßMANN, D. Thomas Manns Roman "Doktor Faustus" und seine Beziehungen zur Faust-Tradition. Helsinki: Suomalainen Tiedeakatemia, 1975.

BENJAMIN, W. Der Erzähler. In: . Iluminationen. Ausgewählte Schriften 1. Frankfurt/Main: Suhrkamp, 1999. p.385-412.

. Literaturgeschichte und Literaturwissenschaft. In: Angelus Novus: Ausgewäblte Schriften 2. Frankfurt/Main: Suhrkamp, 2000. p.450-6.

BOLLE, W. O pacto no Grande sertão - esoterismo ou lei fundadora? Revista USP, São Paulo, n.36, p.27-44, 1997-1998.

O sertão como forma de pensamento. Scripta, Belo Horizonte, v.2, n.3, p.261-3, 1998 .

. Geschichte. In: OPITZ, M.; WIZISLA, E. (Org.) Benjamins Begriffe. Frankfurt/Main: Suhrkamp, 2000. p.399-442.

CARLSSON, A. Das Faustmotiv bei Thomas Mann. In: WOLFF, R. (Org.) Thomas Manns Dr. Faustus und die Wirkung 1. und 2. Teil. Bonn: Bouvier, 1983. p.84-105.

COSTA, H. Sobre as afinidades eletivas: Guimarães Rosa e a Alemanha. Revista USP, São Paulo, n.22, p.111-27, 1994.

COSTA LIMA, L. Terra ignota: a construção de Os sertões. Rio de Janeiro: Civilização Brasileira, 1997. p.193-207. 
COUTINHO, E. Prefácio - Guimarães Rosa: um alquimista da palavra. In: ROSA, G. Ficção completa. Rio de Janeiro: Nova Aguilar, 1995. p.11-24.

CUNHA, E. da. Os sertões. Campanha de Canudos. Rio de Janeiro: Francisco Alves, 1995.

DURÃES, F. S. O mito de Fausto em Grande sertão: veredas. Rio de Janeiro: Academia Brasileira de Letras, 1999.

ETTE, O. ÜberLebenswissen. Die Aufgabe der Philologie. Berlin: Kadmos, 2004.

FINAZZI-AGRÒ, E. O tamanho da grandeza - Geografia e história em Grande sertão: veredas. Scripta, Belo Horizonte, v.2, n.3, número especial Guimarães Rosa, p.108-14, 1998.

GINZBURG, J. Guimarães Rosa e o terror total. In: VIII CONGRESSO INTERNACIONAL BRASA NA VANDERBILT UNIVERSITY. Anais... Nashville, Tennessee, 13 a 16 de outubro de 2006 (no prelo).

GOCKEL, H. Faust im Faustus. In: Thomas Mann Jabrbuch 1. Frankfurt am Main: s. n., 1988. p.133-48.

KUTZENBERGER, S. Europa in Grande Sertao: Veredas - Grande Sertao: Veredas in Europa. Amsterdam: Rodopi, 2005.

LORENZ, G. W. Diálogo com Guimarães Rosa. In: ROSA, J. G. Ficção completa. Rio de Janeiro: Nova Aguilar, 1995. p.27-61.

LLERAS, G. H.-O. Die produktive Rezeption von Thomas Manns Doktor Faustus. Heidelberg: C. Winter, 1995.

LUKÁCS, G. Die Tragödie der modernen Kunst. In: WOLFF, R. (Org.) Thomas Manns Dr. Faustus und die Wirkung 1. und 2. Teil. Bonn: Bouvier, 1983, p.34-83.

MADEIRA FILHO, W. O discurso do demônio. Leitura comparada dos romances Doktor Faustus (1947), de Thomas Mann, e Grande sertão: veredas (1956), de João Guimarães Rosa. Rio de Janeiro, 1998. Tese (Doutorado) - Pontifícia Universidade Católica.

MANN, T. Deutschland und die Deutschen. In: Bänden. Frankfurt/Main: Fischer, 1990. v.XI, p.1126-48. Gesammelte Werke in dreizehn Doutor Fausto. A vida do compositor alemão Adrian Leverkühn. Trad. Herbert Caro. Rio de Janeiro: Nova Fronteira, 2000.

NIETZSCHE, F. Also sprach Zarathustra. In: Werke. Frankfurt am Main: Zweitausendeins, 1999. v.1, p.545-778.

OLIVEIRA, F. de. Ficção brasileira. In: A fantasia exata: ensaios de literatura e música. Rio de Janeiro: Zahar, 1959. p.176-86.

Romance do purgatório. In: Guimarães Rosa: viola d'amore. Rio de Janeiro: Edições do Val, 1965. p.113-24.

PLESSNER, H. Die verspätete Nation: über die politische Verfügbarkeit bürgerlichen Geistes. Frankfurt/Main: Suhrkamp, 2001.

ROSA, J. G. Grande sertão: veredas. Rio de Janeiro: Nova Fronteira, 1986. Ave, palavra. Rio de Janeiro: Nova Fronteira, 2001.

SCHWARZ, R. Grande sertão: estudos. In: COUTINHO, E. (Org.) Guimarães Rosa. 
Rio de Janeiro; Brasília: Civilização Brasileira; Instituto Nacional do Livro, 1983. p.37889. (Col. "Fortuna Crítica", v.6).

SCHWERTE, H. Faust und das Faustische. Ein Kapitel deutscher Ideologie. Stuttgart: Klett, 1962.

SOETHE, P. A. Ethos, corpo e entorno: sentido ético da conformação do espaço em Der Zauberberg e Grande sertão: veredas. São Paulo, 1999. Tese (Doutorado em Letras) Faculdade de Filosofia, Letras e Ciências Humanas, Universidade de São Paulo.

SPERBER, S. F. Caos e cosmos: leituras de Guimarães Rosa. São Paulo: Livraria Duas Cidades; Secretaria da Cultura, Ciência e Tecnologia dos Estado de São Paulo, 1976.

VAGET, H. R. Kaisersaschern als geistige Lebensform. Zur Konzeption der deutschen Geschichte in Thomas Manns Doktor Faustus. In: PAULSEN, W. (Org.) Der deutsche Roman und seine historischen und politischen Bedingungen. Bern; München: Rancke, 1977. p.200-35.

VEJMELKA, M. Kreuzwege: Querungen. João Guimarães Rosas Grande sertão: veredas und Thomas Manns Doktor Faustus im interkulturellen Vergleich. Berlim: Edition Tranvía, 2005.

"Homem desregulado" - João Guimarães Rosas “deutsche Erzählungen” in Ave, palavra. Anuário Martius-Staden, São Paulo, n.55, p.97-120, 2008a.

Hetaera esmeralda, a "borboleta brasileira": uma chave para a recepção do Doutor Fausto de Thomas Mann no Brasil. In: SIMPÓSIO INTERNACIONAL FAUSTO E A AMÉRICA LATINA. São Paulo: Faculdade de Filosofia, Letras e Ciências Humanas da USP, 2008b (Manuscrito).

WIßKIRCHEN, H. Verbotene Liebe: Das Deutschland-Thema im “Doktor Faustus". In: WIßKIRCHEN, H.; SPRECHER, T. (Org.) "Und was werden die Deutschen sagen?”: Thomas Manns “Doktor Faustus”. Lübeck: Dräger, 1998. p.179-210.

ZIMA, P. V. Komparatistik: Einführung in die Vergleichende Literaturwissenschaft. Tübingen: Francke, 1992.

RESUMO - Grande sertão: veredas, de João Guimarães Rosa, e Doutor Fausto, de Thomas Mann, são colocados em uma leitura dialógica orientada por temáticas comuns - a figura do Fausto e do pacto -, mas especialmente por convergências em nível narrativo - o uso da alegoria e a elaboração de metáforas espaciais para a reflexão crítica da história. A um breve comentário dos estudos comparados existentes a respeito dos romances, segue-se a análise dos aspectos mencionados em três exemplos: a presença da tradição do Fausto nos dois romances, os dois pactários Riobaldo e Adrian Leverkühn como alegorias do Brasil e da Alemanha no século XX e as funções narrativas da cidade fictícia de Kaisersaschern e do Liso do Suçuarão.

PALAVRAS-CHAVE: João Guimarães Rosa, Thomas Mann, Grande sertão: veredas, Doutor Fausto, Pacto, Literatura comparada.

ABSTRACT - João Guimarães Rosa's Grande sertão: veredas and Thomas Mann's Doctor Faustus are interpreted in form of a dialog guided by common themes - like Faust and the pact -, but primarily by convergences on the narrative level - like the uses of alle- 
gory and the treatment of spatial metaphors in order to critically reflect History. After a short comment on already existing comparative studies of the two novels, I will analyze the above mentioned aspects by three examples: the presence of the Faust tradition in the novels, Riobaldo and Adrian Leverkühn dealing with the devil as allegories of $20^{\text {th }}$ century Brazil and Germany, and the narrative functions of the fictitious town of Kaisersaschern and the sertão's Liso do Suçuarão.

KEYWORDS: João Guimarães Rosa, Thomas Mann, Grande sertão: veredas, Doctor Faustus, Pact, Comparative literature.

Marcel Vejmelka é graduado em Tradução (português, espanhol, ciências políticas) pela Universidade Humboldt, com dissertação sobre A obra de Jorge Amado na Alemanha Oriental e Ocidental. Suas traduções e recepções; doutorado em Estudos Latino-Americanos pela Universidade Livre, ambas de Berlim, com a tese Kreuzwege: Querungen. João Guimarães Rosas Grande sertão: veredas und Thomas Manns Doktor Faustus im interkulturellen Vergleich; bolsista (2007-2008) de pós-doutorado do International Graduate Centre for the Study of Culture (GCSC) da Universidade Justus Liebig de Giessen. @- marcel@vejmelka.de

Recebido em 29.9.2008 e aceito em 7.12.2008. 